\title{
Authority of the State of the President in a State of Emergency
}

\author{
Verrie Hendry ${ }^{1}$ and Salman El Farisiy ${ }^{2}$ \\ \{hendry.hendryman@gmail.com\} \\ ${ }^{1,2}$ University of Jayabaya, Indonesia
}

\begin{abstract}
As a result of the crisis due to the Corona virus or COVID-19 outbreak, on March 31, 2020, President Jokowi issued 3 (three) regulations, namely 1) Government Regulation Number 1 of 2020 concerning State Financial Policy and Financial System Stability for Corona Management. Virus Disease 19 and in the Context of Facing Threats to Disturb the Stability of the National Economy and Financial System; 2) Government Regulation Number 21 of 2020 concerning Large-Scale Social Restrictions in the Context of Accelerating the Management of COVID-19; 3) Presidential Decree Number 11 of 2020 concerning the Determination of the Public Health Emergency for COVID19. Then on April 13, 2020, the issuance of Presidential Regulation Number 12 of 2020 concerning the Stipulation of the Spread of the Corona 19 Virus Disease Non-Natural Disasters as a National Disaster. The purpose of this paper is to study the regulations for the formation of state policies in emergency/danger situations. The Covid-19 threat is a security threat for all of us. Let us unite to face and overcome it, regardless of political attitudes and political polarization in society. "Salus poluli suprema les esto", the safety of the people is the highest law. "Needs have no legem." The importance of salvation is lawless, but above all is law. regardless of political attitudes and political polarization in society. "Salus poluli suprema les esto", the safety of the people is the highest law. "Needs have no legem."
\end{abstract}

Keywords: Authority, State of Emergency, President

\section{Introduction}

The World Health Organization (WHO) declared a public health emergency caused by the existence of the Corona virus officially on February 11, 2020 which came to the attention of the international community (Public Health Emergency of International Concern / PHEIC). ${ }^{1}$ Then on March 11, 2020 through the Director General of WHO Dr. Tedros Adhanom Ghebreyesus stated that based on the recommendations, COVID-19 could be categorized as a pandemic. ${ }^{2}$

In February 2020 WHO has established the Guidelines for the Country Preparedness and Response Plan (CPRP) through the standards and norms of the International Health Regulation (IHR) in 2005, in which Indonesia has been a state party since 2007, as a reference for integrated, coordinative, consultative and deliberative work policies. for all countries[1].

\footnotetext{
${ }^{1}$ https://www.who.int/dg/speeches/detail/who-director-general-s-statement-on-ihr-emergency-comm committee-on-novel-coronavirus- (2019-ncov)

${ }^{2}$ https://www.who.int/dg/speeches/detail/who-director-general-s-opening-remarks-at-the-media-briefingon-covid-19---11-march-2020
} 
For Indonesia, the entry of the COVID-19 pandemic has drastically changed the activities of people's lives today. This complicates matters by requiring education and carrying out work from home. Also very risky to the pattern of resilience of community household life. Of course, Indonesia's future will be marked by the head or backbone of the family who has lost their jobs, declining incomes, limited logistics and access to other life necessities.

This is a test of the country's government system as well as human values. The State of Indonesia, in this case the Government and ministries / agencies, local governments and security actors are required to optimize their strength together with all elements of society to unite in facing this bad reality.

Through Presidential Decree No. 7 of 2020 President Jokowi has appointed the Head of BNPB as Chair of the Task Force for the Acceleration of Handling COVID-19, which has been amended by Presidential Decree No. 9 of 2020 and Presidential Instruction No. 4 of 2020 to support changes to the APBN and APBD.

The most recent and known, on March 31, 2020 President Jokowi issued 3 (three) regulations, namely 1) Perpu No. 1 of 2020 concerning State Financial Policy and Financial System Stability for Handling the Corona Virus Disease 19 Pandemic and / or in the Context of Facing Threats that Endanger the National Economy and / or Financial System Stability; 2) PP No. 21 of 2020 concerning Large-Scale Social Restrictions in the Context of Accelerating the Management of Corona 19 Virus Disease (COVID-19); 3) Presidential Decree No. 11 of 2020 concerning the Determination of the Corona Virus Disease 19 (COVID-19) Public Health Emergency. Then followed on April 13, 2020, the issuance of Presidential Decree No.12 of 2020 concerning the Determination of Non-Natural Disaster for the Spread of Corona Virus Disease 19 (COVID-19) as a National Disaster.

However, important regulations that have been issued by the community are immediately accepted by the community. After the issuance of the Perpu, a number of legal figures and experts agreed. They continue to conduct studies related to this Perpu and will file a judicial review against it. According to data from the Constitutional Court, during April 2020, three petitioners have submitted their lawsuit to the Constitutional Court. ${ }^{3}$ They considered that the Perpu was unconstitutional and had to be tested for material.

When looking at the substance in this Perpu, the focus of discussion is precisely the economy that saves humanity. The current situation in the field is the number of casualties, both patients and medical personnel. Especially when medical personnel who are victims and the implementation of Large-Scale Social Restrictions (PSBB) are still unable to meet the needs of the community by the government, there are still many problems in their implementation that are not on target.

Instead of discussing State Financial Policies and Financial System Stability in Handling the Corona Disease 19 Pandemic, the main point that urges rescue is ignored and focuses on saving the economy.

It was that the test of matter is put to the Constitutional Court, namely the material content of Article 27 concerning granting legal immunity to officials is one of the highlights of the problem in Perpu No. 1 of 2020, in addition to unconstitutional problems. The content of article 27 is not in line with the responsibility of the central government with limited steps in dealing with the Corona 19 Virus disease (COVID-19) pandemic through the PSBB. Even if it is in an emergency situation, the government should have taken certain area quarantine measures from the start to prevent the spread of the Corona Disease 19 (COVID-19) Virus.

\footnotetext{
${ }^{3}$ https://mkri.id/index.php?page=web.EFormPUUDetail\&id=2
} 
It was that the test of matter is put to the Constitutional Court, namely the material content of Article 27 concerning granting legal immunity to officials is one of the highlights of the problem in Perpu No. 1 of 2020, in addition to unconstitutional problems. The content of article 27 is not in line with the responsibility of the central government with limited steps in dealing with the Corona 19 Virus disease (COVID-19) pandemic through the PSBB. Even if it is in an emergency situation, the government should have taken certain area quarantine measures from the start to prevent the spread of the Corona Disease 19 (COVID-19) Virus.

In Presidential Decree No. 11 of 2020 in the weighing section states that the spread of Corona Virus Disease 2019 (COVID-19) which is of extraordinary character with the number of cases and / or the number of deaths has increased and spread across regions and across countries and has an impact on political, economic, social, cultural aspects, defense and security, as well as the welfare of the people in Indonesia[2]. This clearly shows that the consequences of this pandemic have an impact on political, economic, social, cultural, defense and security aspects as well as public welfare. However, Perpu No. 1 of 2020 published only about assistance regarding saving state finances. Likewise with a review of the considerations of the Presidential Decree No. 12 of 2020, namely a non-natural disaster caused by the spread of Corona Virus Disease 2019 (COVID-19) has had an impact on the number of victims and property losses, the extent of the area affected by the disaster, and has implications for broad socio-economic aspects in Indonesia[3].

Therefore, the question arises why the Presidential Decree for Emergency Public Health and the Presidential Decree for National Disaster along with the Perpu have considerations? Although it is clear that the incident is in a state of emergency and of an extraordinary nature, the number of cases and / or the number of deaths has increased and spread across regions and across countries and has an impact on political, economic, social, cultural, defense and security, as well as public welfare and the government's efforts to tackle the Corona 19 Virus Disease (COVID-19) and handling the implications of the pandemic.

Supposedly, with the determination of this Public Health Emergency and National Disaster, the government is expected to be more focused on resolving the break in the distribution chain by paying attention to all the points of impact that have been caused. In fact, handling the impact of this post-disaster should be the government's main focus. However, the principle of caution must be put forward in issuing regulations.

When the normal law cannot function, another law, namely the law of emergency must come into play. It is therefore very important to distinguish legal regimes in theory and practice, namely normal constitutional law and emergency constitutional law[4].

The issuance of Laws and Perpu must not contradict the Constitution, with permission for and in an emergency which is permitted for a limited time and is closely monitored, overriding or postponing the enactment of a provision of the 1945 Constitution with the intention of overcoming a state of danger until it becomes recovered under the provisions of Article 12 of the Constitution. 1945. The provisions of this article state that, "The President declares danger. The terms and effects of the danger are seen by law". And Article 12 of the 1945 Constitution becomes very clear when paired with Article 22 paragraphs (1), (2) and (3) of the 1945 Constitution which states:

(1) In the event of any crisis that comes, the President has the right to be a manenforce government regulations as law;

(2) This government regulation must be approved by the DPR in the following sessions;

(3) If it does not get approval, the government regulation must be revoked.

In this paper the author would like to be particularly interested in Perpu No. 1 of 2020 concerning State Financial Policy and Financial System Stability for Handling the Corona 
Virus Disease 19 Pandemic and / or in the Context of Facing Threats that Endanger the National Economy and / or Financial System Stability, in relation to Presidential Decree No. 11 of 2020 concerning the Determination of Public Health Emergency for Corona Virus Disease 19 (COVID-19) and Presidential Decree No. 12 of 2020 concerning the Determination of Non-Natural Disaster for the Spread of Corona Virus Disease 19 (COVID19) as a National Disaster. Because none of the three have paid attention to Article 12 of the 1945 Constitution in advance of the Perpu No. 1 of 2020.

Referring to the 1945 Constitution which has undergone changes, according to Jimly[5], Amendments to the 1945 Constitution must be beneficial for the improvement of the nation's welfare, in accordance with the aspirations of the people and the development of the life of the Indonesian nation. In order for the amendment to the 1945 Constitution to have legal force, the amendments to the 1945 Constitution must have a clear legal basis / basis.

With the aim that we can better understand government regulations in making policy decisions that are of an emergency (state of emergency) because it does not rule out the possibility that a situation like the present could be more emergency / dangerous in the future. Therefore it is important for us to have an understanding of what forms of Perpu, their ordering and their withdrawal.

Based on the description of the State in a state of emergency, the problem formulations in this paper are:

1. Is with the issuance of Perpu No. 1 of 2020 is in accordance with the completion and handling of the impact of Corona Virus Disease 2019 (COVID-19)?

2. How is the 1945 Constitution policy regulation in the settlement and handling of a pandemic in which the State is in a state of emergency?

\section{Method Research}

This research is a normative-empirical legal research. Empirical legal research means research conducted directly in the community, in contrast to normative legal research which uses secondary data in the form of literature search results.[6]. This research will combine the normative and empirical legal approaches. Empirical legal research is commonly referred to as sociological legal research or field research. Tracing data in the field can be done by observation (observation), interviews or distributing questionnaires. Another reason that he chose to base his empirical legal research method is that the research examines not only legal issues, but also human rights issues. Legal research that can be carried out with other disciplines, namely sociology and anthropology. Normative legal research is carried out on the study of the 1945 Constitution before and after the amendment. Secondary data studies were also carried out with literature studies on related issues.

\section{Discussion}

\subsection{President's Authority}

In a democracy, sovereignty or supreme power rests in the hands of the people, not in the hands of people's representatives or the hands of the head of state and head of government. This is emphasized in Article 1 paragraph (2) of the 1945 Constitution, "Sovereignty is in the hands of the people, and is exercised according to the Constitution". In a democracy, the people who are self-supporting are sovereign in accordance with the principle of autonomy where the words "auto" and "nomos" mean self-help. People through their representatives in 
the DPR, according to Article 20 paragraph (1) of the 1945 Constitution, are the holders of the power to form laws. Whereas in Article 5 paragraph (1) of the 1945 Constitution, the President is only entitled to appeal for drafting the DPR bill. ${ }^{4}$

Thus, generally binding regulations can only be implemented by the people through their representatives in the DPR. Or done based on the order or authority of the delegation based on law (legislative delegation of rule-making power). Also matters that really need to be regulated by the government based on the attribution of authority according to the Basic Law. By applying, based on the 1945 Constitution, the President as the head of a built government or "rule of power" in the following categories:

1) Article 5 paragraph (1) of the 1945 Constitution provides that the President has the right to submit a bill to the DPR. In addition, the President discussed together the bill to give approval or rejection of the bill according to Article 20 paragraph (2) and (3) of the 1945 Constitution, and finally health also ratified the bill that had received joint approval into law which should be according to Article 20 paragraph (4). ) and (5) the 1945 Constitution.

2) Government Regulation as Law as referred to by Article 22 of the 1945 Constitution which states, "In the event of a crisis that comes, the President can refer to government regulations as law". This legal product is called PERPU which can be regulated in an ordinary situation or in an emergency situation;

3) Government Regulation atribusian UUD 1945 as referred to by Article 5 aat (2) UUD 1945 which states, "The President stipulates the provisions of government regulations to implement laws regulating mustya". This is the authority of attribution by the Constitution, ordered or not by law, the President can issue a PP to fill a legal vacuum or to enforce the law properly.

4) Government Regulations Legislation delegation refers to Law no. 12 of 2011 concerning the Formation of Legislative Regulations. If the law mandates the Government to further finance a statutory provision, the President has the authority to determine Government Regulations based on the delegation of authority by law.

5) Presidential Regulation (PERPRES) which can be stipulated by the President, either on the basis of a delegation of further regulations based on Law or Government Regulation, or based on the principle of "frij ermessen" in which the President as head of state and head of governance administers by himself assisting matters which administratively, and (ii relating to internal government matters in the form of a Presidential Regulation.

6) Ministerial Regulation (PERMEN) as the basic rule of delegation authority based on Law, Government Regulation, and / or Presidential Decree. On the basis of the delegation or delegation of further regulatory authority based on the above mentioned Law, Government Regulation or PERPRES on the basis that further sub-delegation of authority, or subdelegation of regulatory authority, is idealized as an official with the lowest authority that can be given regulatory authority.

The regulatory authority or the power to regulate rests with the President as head of government, limited only to the above. Apart from the foregoing, the President may not have constitutional powers that have been determined based on the 1945 Constitution, including in using the Perpu instrument to make new policies that are permanent or temporary in nature.

\footnotetext{
${ }^{4}$ Amendment, Article 5 paragraph (1) of the 1945 Constitution reads, "The President holds the power to form laws with the approval of the DPR". With the First Amendment to the 1945 Constitution in 1999, this article changed to, "The president has the right to submit a bill to the DPR", while Article 20 paragraph (1) of the 1945 Constitution became "the DPR holds the power to form laws".
} 
In addition, the total hierarchy of statutory regulations above must be consistent, must not conflict with legal norms above it. A higher legal norm which presupposes the validity of the legal norm that is under it. Therefore, PERMEN must not conflict with PERPRES, PERPRES must not conflict with PP, and PP must not conflict with Law. Meanwhile, Law and PERPU must not contradict the UUD, except for PERPU for and in an emergency which is permitted for a limited time and is closely monitored to override or suspend the enforcement of a provision of the 1945 Constitution to overcome a state of danger until it returns based on the provisions of Article 12 of the 1945 Constitution.

However, it has been stated above, PERPU No. 1 of 2020 cannot be categorized as a PERPU for and in this emergency situation, because it does not at all apply to the provisions of Article 12 of the 1945 Constitution. The provisions of Article 12 are a statement "The President declares a state of danger. The conditions and consequences for the situation of danger are determined by law". From Article 12 it can be seen that:

1) The legal requirements and consequences of a state of danger are established by law in the sense that the statement of the state of danger is stipulated by a law which regulates special policies that are implemented to solve the problem and return to its original state; and

2) The conditions and legal consequences of an emergency need to be further regulated in the laws included. Until now, the law that is still in effect regarding this matter is Law no. 23 of 1959 concerning State of Danger, but many of its contents are no longer in accordance with the times, including the new provisions of the 1945 Constitution after the First, Second, Third, and Fourth Amendments in 1999-2002.

\subsection{About Perpu}

PERPU is short for Government Regulation in Lieu of Law, as the name of the Old Order era, New Order era, and until now in the post-Reformation era, in referring to government regulations that are used as laws, when the President needs to enact new policies established by law. -invited. However, due to precarious circumstances, this regulation has not yet been submitted to the DPR, so it is deemed sufficient in the form of a government regulation or PERPU for a while. Therefore, PERPU itself is in the form of a Government Regulation. As formulated in the 1945 Constitution in Article 22 paragraphs (1), (2), and (3), which reads:

(1) In the event of any crisis that comes, the President has the right to determine regulations as laws;

(2) This government regulation must be approved by the DPR in the following sessions;

(3) If it does not get approval, the government regulation must be revoked.

Based on the provisions of Article 22, PERPU is nothing but a Government Regulation containing normative policies on the contents of the Law which was formed through a joint agreement by the DPR and the President in accordance with the provisions of Article 20 paragraph (2) of the 1945 Constitution. However, due to the precarious conditions In the provisions of Article 22 paragraph (1), the material of the law is poured out temporarily in the form of a PERPU until it is later approved by the DPR so that its status is officially changed to an ordinary law. The 1945 Constitution itself does not mention the official name of this type of regulation, because in 1945 this matter had not been thoroughly discussed by the drafters of the 1945 Constitution. Therefore, at the time Soepomo and his friends rearranged the text of the 1949 RIS Constitution, The naming of this new regulation is standardized in the 
formulation of the RIS Constitution under the name emergency law, which is established for emergencies. A name that continued to be used until the drafting of the 1950 Constitution.

In other words, from the beginning of the Order of the 1945 Constitution, it is actually, with government regulations the law in the formulation of Article 22 of the 1945 Constitution is an emergency law. Namely, laws that are formed for and in an emergency or in a state of danger that exists in Article 12 of the 1945 Constitution. Thus, the meaning of government regulation as a law that applies Article 22 of the 1945 Constitution, must use in its circumstances with the provisions concerning the circumstances. dangers regulated in Article 12 of the 1945 Constitution. Do not control both.

The development of the definition of PERPU as a provisional law does not mean that the PERPU, which is related to the provisions of Article 12 of the 1945 Constitution, which originated from the initial thought, does not function. PERPU which was formed and is in a state of danger according to Article 12 of the 1945 Constitution is still implemented differently and changes as an emergency law from an unusual meaning which does not constitute a temporary law. These two types of PERPU will be covered in the next section. What is clear, evidence-both exist and constitutionally valid. One is valid because its existence is determined according to the 1945 Constitution, namely (i) to determine the status of danger, (ii) to regulate special policies to be used in order to overcome hazards or emergencies with policies that are different from ordinary circumstances. Meanwhile, the second, arises from later interpretations that grow in practice into constitutional conventions which are also a form of informal constitutional amendments (formal amendments). Namely through the practice of constitutional conventions (constitutional conventions) according to CF Strong[7] also valid as a method of changing the modern constitution.

However, it also needs to be emphasized first, that from the description of the nature of the PERPU form as a government regulation, we can distinguish between the legal form and the material norms in regulatory regulations. The form of PERPU is a Government Regulation (PP) whose content is the material of Law (UU). Because of that, in fact PERPU is indeed a Government Regulation which is temporarily stipulated as law until the DPR is approved so that it is officially transformed into Law in due time. This means that PERPU can apply it as a temporary law, because in time it will change its status to become law. Therefore, all substantive requirements regarding regulation by law also apply to PERPU in the meaning of this law. In terms of this PERPU is a law,

Therefore, one must be aware of the difference and distinction between form and content, between structure and substance, and theory and practice. Theoretically, it can happen that the material being enforced is legal material, but by the Government it is set forth in the form of a Government Regulation or in the form of a Presidential Regulation. The same thing may happen when there is material normative policy that should be written in the form of Regional Regulation (PERDA), which the Regional Head states as a Regional Head Regulation (PERKADA). If the DPR and DPRD that supervise are not active in carrying out substantive normative oversight functions with regard to ordering regulations, which should only be implementing regulations of regional laws or regulations, then the products of "executive action" It runs very smoothly regardless of the legislative role of people's representative institutions at the central or regional levels. This can happen if the oversight function by the people's representative institutions does not work well. Supervision is not only related to the implementation of programs and implementation of government and development action programs, but also the supervision of the elaboration of policies contained in the form of laws as products of legislation into implementing regulations of laws as products of executing executive actions). 
Therefore, it is very important to understand the meaning of "wet in formeele zin" and "wet in material zin" properly, so that it can be distinguished between the material context and its legal form. In carrying out their examining function, both the judges in the Constitutional Court and the Supreme Court must also be really aware of recommendations. So that there is no hurry in determining the attitude towards the proposed examiner. Only because the formal form is in the form of a regulation under a law, the Constitutional Court may not immediately declare that a regulation that contradicts the 1945 Constitution does not apply. A regional regulation can also be a regulation formally under a law but materially, has rules as material invited.

Many people misunderstand the nature of PERPU and fail to understand the understanding between the two types of PERPU in our constitutional system. Based on the 1945 Constitution, explosions can be distinguished as:

1) PERPU as an ordinary law has not received DPR approval based on Article 22 of the 1945 Constitution which is temporary, due to the precarious conditions that have entered;

2) PERPU for and in state conditions which are in a state of emergency or in a state of danger according to Article 12 jo Article 22 of the 1945 Constitution.

Usually people talking about PERPU are only fixated on information about what is meant by "the urgency that is sent" as determined by Article 22 paragraph (1) of the 1945 Constitution. As quoted above, Article 22 paragraph (1) determines, "(1) In the event of any crisis that comes, the President has the right to determine regulations as laws ". In the legal consideration of decision Number 138 / PUU-VII / 2009, the Constitutional Court has outlined 3 conditions that must be fulfilled for the conditions that are entered, namely: (1) the proximity of requirements to resolve legal problems quickly based on the law; (2) The required law does not exist yet, so there is a legal vacuum, or there is a law but it is not sufficient; and (3) The legal vacuum cannot be resolved by making a law according to the usual procedure because it will take a long time while the proximity of the situation requires certainty to be excessive. However, these three requirements are still general in nature, not at all prepared for a situation that is very different between a hazard that is an emergency, a normal situation that is not an emergency.

Apart from that, these requirements are still too general, they must always be relevant to ordinary situations. Although the three of them can also survive the state of emergency as referred to in Article 12 of the 1945 Constitution, the requirements for PERPU in an emergency state require more detailed requirements, the relationship of which the conditions and consequences of the law of an emergency are very different from ordinary circumstances. The legal needs in this situation certainly require different legal means. The two situations require a legal regime that is very different from one another, because normal circumstances can only be approached by a legal regime that is also normal, while a state of danger or emergency that causes abnormal conditions must be approached with a legal regime that is also abnormal. "Normale rechts voor normale tijd,

Because the two PERPUs should be differentiated and validated from one another. In terms of statutory orders, reminders are equally constructed in an unusual manner, in a way that deviates from the usual provisions. However, in terms of the substance of the norm, it is very different. The first type of PERPU is a policy policy that controls policies that are contained in a basic law in general, while the material for the second PERPU policy is purely for a limited time, namely for and during an emergency, not for purposes of a permanent nature. 
The Perpu which was first stated above, is currently a law in general, which is intended to take effect at the time after obtaining the approval of the DPR, and will act as an ordinary law; or if the DPR does not approve, then PERPU must be revoked. PERPU contains policies that are important to be immediately put into law, but due to the urgency of being included, there is not enough time to submit, discuss, and get joint approval with the DPR-RI to pass them into law. Therefore, the new policies referred to in the form of Government Regulations in lieu of laws or PERPU for the time being, until the approval of the DPR can obtain approval from Article 22 paragraph (2) of the 1945 Constitution. Thus the status is an ordinary law as in general. This first type of PERPU can change various provisions in other laws and even practice the "omnibus" method of changing many laws at once. Provided that the material does not conflict with the 1945 Constitution of the Republic of Indonesia.

Meanwhile, there is no permanent concern for the PERPU type. Only temporarily during an emergency. The functions of this second PERPU are: (i) can be used as a means of enforcing emergencies, as well as (ii) as a means of pouring out specific legal policies to overcome and overcome problems that arise during a hazard or emergency; and (iii) as a means to improve the situation so that it returns to its original state according to the normal legal system; and (iv) arrangements regarding the withdrawal or termination of a state of emergency after the arrangement regarding all hazards or emergencies is declared to have ended, in Transitional provisions or Closing provisions. As a temporary legal product for and in emergencies, government action in an emergency (Emergency Powers) can suspend or override various other statutory provisions. It has even postponed the articles in effect regarding human rights and others that have been determined and guaranteed by the 1945 Constitution.

This action to rule out or suspend cannot be done by the first type of PERPU. Because the first type of PERPU is an ordinary law that cannot contradict the 1945 Constitution.

If the conditions for ordering these two types of PERPU are more detailed, including the two conditions at once, the criteria for the criteria formulated by the Constitutional Court can be further clarified into the following four criteria:

1) The existence of a need for closeness (urgent need) based on the principle of "rule of needs" in general or in a state of emergency requires state government officials to act to resolve problems that arise related to the public interest or the interests of the state which the victim does not commit. or if done will violate the applicable law.

2) The existence of compelling needs which is based on the principle of "rule of needs" in general or in a state of emergency requiring the enactment of new policies that are not enforced will be detrimental to the public interest or the interests of the state but enforced will violate appropriate laws .

3) Both of these must be resolved immediately by enacting a new law, but the process of ordering it according to the usual procedure was impossible due to time constraints (limited time limits), so that the joint agreement with the DPR was not possible to fulfill the request properly.

4) If the three criteria above are met, then the President has the right to determine the Government Regulation in Lieu of Law, namely:

A. In ordinary circumstances, the PERPU functions as a provisional law until it is approved by the DPR so that the PERPU is changed to the law used by Article 22 paragraph (2) of the 1945 Constitution, or the PERPU must have the DPR's approval as meant by Article 22 paragraph (3) the 1945 Constitution. 
b. In a state condition in a state of emergency, PERPU is stipulated to withdraw or simultaneously with a declaration or statement of a state of danger or the imposition of a state of danger / emergency by the President who is in a proper condition according to Pas long as 12 UUD 1945 junto Article 22 UUD 1945. This PERPU is an emergency law that only exists for emergency response.

From the description above, it can be formulated that there are two absolute conditions for the issuance of a PERPU, both the first type and the second type, namely: (i) there is an absolute need for closeness or absolute requirements to enforce a new law, and (ii) there are limitations time to follow the usual procedures in statutory processing (time limits). In fact, in a state in a state of emergency, it is also required (iii) to enforce or declare the state of emergency itself as an absolute requirement for the validity of the enforcement of PERPU as an emergency law.

PERPU as an emergency law is intended only temporarily during an emergency and is precisely necessary to overcome everything during the emergency period. Meanwhile, PERPU as a temporary law, is intended as an ordinary law containing policies that are intended to continue permanently. The reason for this urgency goes to the basis of deviating from the procedure, but the material still follows the usual rules of law-making. Meanwhile, the reason for the urgency that is included in an emergency condition can become the basis for the President to determine PERPU in the emergency law by deviating from the usual constitutional rules.

\subsubsection{Perpu enforcement}

What is the procedure for applying PERPU? In simple terms, at any time, the President considers there is a need that is very close and cannot be postponed regarding government policies that need to be implemented, however, if implemented without first regulating them by law, then the policy will violate the law, then the need arises. real to form new laws. However, in the time available, there is not enough time to form a law according to the usual procedure, so that in a situation of urgency, the provisions of Article 22 paragraph (1) of the 1945 Constitution apply which authorizes the President to regulate government regulations as statutory rules. (PERPU). Thus, the President can enforce the PERPU unilaterally at any time he thinks is needed. provided that the PERPU is only temporary until the next DPR trial, it is proposed by the President to further seek mutual approval by the DPR-RI in accordance with the provisions of Article 22 paragraph (2) of the 1945 Constitution, the PERPU will be turned into law. If it is not approved, PERPU must be revoked in accordance with the provisions of Article 22 paragraph (3) of the 1945 Constitution.

Because PERPU is a legal product of the President, the PERPU text is written in the Head of the Presidential Letter of the Republic of Indonesia, not yet in the form of a Law. PERPU's numbering has not been based on the numbering of laws promulgated in the State Gazette and the Supplement to the State Gazette. However, because of the type of PERPU, which is described as being of two kinds, namely PERPU in ordinary circumstances but fulfilling the urgent requirements that are included in Article 22 of the 1945 Constitution, and PERPU which is determined to be in an emergency according to Article 12 of the 1945 Constitution, enforcement also requires an explanation. different.

The first PERPU, which is related as a temporary law, until it is approved by the DPR, will automatically be transformed into a law according to policies that will also apply in accordance with laws in general. Meanwhile, the second type of PERPU is PERPU which is set for and in emergencies. The intention is that the PERPU is stipulated (i) to impose a policy 
emergency that is specific and has a temporary period of time until the state of emergency ends, and (ii) in an emergency that has been declared by the President which should be in accordance with the provisions of Article 12 of the 1945 Constitution.

The stipulation of this second PERPU can be preceded by or together with a Presidential Decree which declares a change from a normal state to an emergency according to Article 12 of the 1945 Constitution and the Law on Hazardous Situations. Apart from the Presidential Decree and the PERPU, a Presidential Instruction (INPRES) can be added which is more operational in its implementation by implementing agencies in the field. Thus, there are 3 legal instruments that can be stipulated at the same time on the same day, namely:

1) Presidential Decree which declared a state of emergency;

2) PERPU which contains temporary policies that can suspend the enactment of various other laws. Including special policies that suspend human rights or the enactment of certain provisions in the 1945 Constitution until conditions are restored;

3) INPRES which guides the implementation of operational and technical directions for implementing agencies or agencies, both at the central provincial level, as well as districts and cities throughout Indonesia

Particularly regarding the instrument for implementing an emergency and ending or lifting a state of emergency, it can be debated about two possible instruments, namely (i) by law, or (ii) by a presidential decree. Article 12 of the 1945 Constitution stipulates, "The President declared a state of danger. The conditions and consequences for the situation of danger are determined by law ". With what written legal instrument, did the President declare a situation of danger? In the formulation of Article 12 of the 1945 Constitution, there are 2 things, namely: (i) The President, either to declare the entry into force or to declare the end of the dangerous state, is declared or declared; (ii) the provisions regarding the terms and legal consequences of the state of emergency shall be established by law,

Therefore, the statement "stipulated by law" in the formulation of Article 12 can be interpreted in two senses, namely a general and a special meaning, where (i) the law that regulates general provisions regarding emergencies, and (ii) Law specified specifically to implement emergencies and special assistance for and during the emergency or danger. However, due to the urgency of the entry, this second category of law is set forth in the form of a Government Regulation in Lieu of Law referred to by 22 paragraph (1) of the 1945 Constitution.

In the second sentence the formulation of Article 12 clearly states that "the conditions and consequences of the danger are determined by law". That is, what is stipulated by the law are "conditions and consequences of a state of danger". The conditions are what and what are the consequences that are "stipulated by law". The word "stipulated" here can be implemented to contain the meaning "regulated by law", that is, regarding what are the conditions and what are the consequences of the regulation the meaning of danger must be regulated by law. Thus it can be interpreted that the statement of the entry into force of the emergency or danger does not have to be in the law that reports, but it is sufficient to be stated in an administrative decision, namely a Presidential Decree but the provisions regarding terms and regulations are regulated in advance by or in law. This is clear from the first sentence which determines that the President declared a state of danger. This means that the statement of the state of danger is not in the law which the joint agreement between the DPR and the President states is sufficient by the President alone. Thus, the statement that the conditions and consequences of a situation of danger "are regulated by law" are more accurately regulated in regulating "regulated by law". The law in question can be divided into two forms, namely (i) laws that address hazards in general, and (ii) laws that regulate specific policies for and in case of emergency, until the 
emergency is recovered. . This second category of law, because of the precarious situation and refugees, can be pre-poured in an emergency PERPU. Meanwhile, laws that are generally applicable can also be changed in an emergency situation, so that changes can also be made in the form of a PERPU. For example, Law no. 23 of 1959 was originally PERPU.

\subsubsection{Submission of Draft and Revocation of Perpu}

Law number 12 of 2011 in conjunction with the MD3 Law, states that the revocation of PERPU is carried out with the help of Law. This is deemed inappropriate and should be a backup. Since PERPU is determined unilaterally by the President, it is sufficient for the President to revoke it unilaterally. Presidential Decree (Keppres) as an administrative product. However, Article 52 of Law no. 12 of 2011, determines that:

(1) Government Regulations In Lieu of Laws must be submitted to the DPR in the following sessions;

(2) (2) Submission of Government Regulations in Lieu of Laws referred to in paragraph (1) shall be made in the form of filing Laws concerning the stipulation of Government Regulations in Lieu of Laws into Laws;

(3) The DPR only gives approval or does not give approval to Government Regulations in Lieu of Law;

(4) In the event that a Government Regulation in Lieu of a Law is approved by the DPR at a plenary session, the Government Regulation in Lieu of a Law is stipulated as a Law;

(5) In the event that a Government Regulation in Lieu of a Law does not get the approval of the DPR in a plenary session, the Government Regulation in Lieu of a Law must be revoked and must be declared invalid;

(6) In the event that a Government Regulation in Lieu of a Law must be repealed and must be declared not bound by paragraph (5), the DPR or the President submits a Draft Law on the Revocation of a Government Regulation in Lieu of a Law;

(7) (6) Draft Law on the Revocation of Government Regulations in Lieu of Laws referred to in paragraph (6) the legal provisions of the revocation of Government Regulations in Lieu of Laws;

(8) (7) The Draft Law on the Revocation of Government Regulations in Lieu of Laws referred to in paragraph (7) which is stipulated by the Law on the Revocation of Government Regulations in Lieu of Laws in the same plenary session as referred to in paragraph (5).

According toThe provisions of Article 22 paragraph (2) of the 1945 Constitution, repeatedly by Article 52 paragraph (1) of Law no. 12 of 2011, PERPU must obtain the approval of the DPR-RI at the latest in the following trials. In the Elucidation of Article 52 Paragraph (1), it is emphasized that "What is meant by" the following trial "is the period of the first session after the Government Regulation in Lieu of a Law is enacted." Therefore, the President must submit the PERPU he has enacted to be approved or rejected by the DPR of Ciptanya, before the next session period. According to Article 52 paragraph (2) of the Law, "Submission of Government Regulations in Lieu of Law referred to in paragraph (1) shall be made in the form of filing Laws concerning the stipulation of Laws in Lieu of Laws into Laws".

The meaning, after the stipulation of the PERPU, the Government will immediately compile a Draft Law on the stipulation of the PERPU into law. The same thing must be done if the PERPU does not get approval at the DPRD meeting, namely the DPR or the Government must submit a Draft Law on the Revocation of PERPU as referred to in Article 
52 paragraph (6). The Draft Law on the Revocation of PERPU which is stipulated in the same plenary session as referred to in paragraph (5), which states, "In the event that PERPU does not get the approval of the DPR in a plenary session, the PERPU must be revoked and must be declared invalid". Thus, the plenary session of the DPR which rejects PERPU, and which declares PERPU and declares the law on its repeal is the same plenary session. Therefore,

Ifsuch provisions are obeyed, so there is no need to worry about the protracted stipulation of PERPU into law or its repeal as prevailing statutory regulations. However, the weakness of this regulation can be seen from an administrative point of view. First, PERPU has not yet been promulgated in the State Gazette and the Supplement to the State Gazette, but when it is repealed by law, the revocation will automatically be promulgated in the State Gazette and the Supplement to the State Gazette. Such an arrangement is clearly inappropriate. Second, the PERPU which is stipulated by the President, it should be sufficient for the revocation of it to be carried out by the President as the official who determines the enforcement. The President determines it and the President must revoke it. The control authority by the DPR is sufficient with its authority to declare whether or not the PERPU is valid, while the rest, it is sufficient for the President to determine its revocation. Third, the revocation is carried out by law, meaning that the revocation must be carried out jointly by the President and DPR through a hearing in the DPR. Such a mechanism clearly violates the provisions of the 1945 Constitution which stipulate that "In matters of urgency the President has the right to determine government regulations as law". Therefore, if PERPU is rejected by the DPR, what is meant by Article 22 paragraph (3) of the 1945 Constitution in conjunction with Article 52 paragraph (4) and (5) Law no. 12 of 2011. Revocation is carried out by law, meaning that the revocation must be carried out jointly by the President and the DPR through a hearing in the DPR. Such a mechanism clearly violates the provisions of the 1945 Constitution which stipulate that "In matters of urgency the President has the right to determine government regulations as law". Therefore, if PERPU is rejected by the DPR, what is meant by Article 22 paragraph (3) of the 1945 Constitution in conjunction with Article 52 paragraph (4) and (5) Law No. 12 of 2011. Revocation is carried out by law, meaning that the revocation must be carried out jointly by the President and the DPR through a hearing in the DPR. Such a mechanism clearly violates the provisions of the 1945 Constitution which stipulate that "In matters of urgency the President has the right to determine government regulations as law". Therefore, if PERPU is rejected by the DPR, what is meant by Article 22 paragraph (3) of the 1945 Constitution in conjunction with Article 52 paragraph (4) and (5) Law No. 12 of 2011.

Because it is sufficient for the revocation of PERPU to be declared rejected or not approved by the DPR in the form of a decision signed by the President declaring the PERPU. This means that it is sufficient for the PERPU to revoke it by means of an administrative decision, not in the form of product regulations or legislation. Various provisions regarding the order and revocation of this PERPU must be regulated. Therefore, in Article 53 of Law no. 12 of 2011 also stipulates that "provisions regarding the procedures for drafting a Draft Government Regulation in Lieu of a Law with a Presidential Regulation." The words "regulated by Presidential Regulation" indicate that there should be a Presidential Regulation governing this PERPU. Unfortunately, until now the Perpres in question has not been established. What does exist is Presidential Regulation No. 87 of 2014 concerning the Implementation of Law no. 12 of 2011 concerning Legislative Regulations (LNRI 2014 No. 199). However, the Perpres does not regulate PERPU, the assistance of Law no. 12 of 2011 in general. In fact, Law no. 12 of 2011 mandates to regulate Presidential Regulations relating to PERPU. It should be that matters of an administrative nature regarding the design, submission, approval of becoming laws and the revocation of PERPU are regulated by a Presidential 
Regulation in accordance with the mandate of Article 53 of Law No. 12 of 2011. 199). However, the Perpres does not regulate PERPU, the assistance of Law no. 12 of 2011 in general. In fact, Law no. 12 of 2011 mandates to regulate Presidential Regulations relating to PERPU. It should be, matters of an administrative nature regarding the design, submission, approval become Laws, and the revocation of PERPU is regulated by a Presidential Regulation in accordance with the mandate of Article 53 of Law no. 12 of 2011. 199). However, the Perpres does not regulate PERPU, the assistance of Law no. 12 of 2011 in general. In fact, Law no. 12 of 2011 mandates to regulate Presidential Regulations relating to PERPU. It should be that matters of an administrative nature regarding the design, submission, approval to become Laws and the revocation of PERPU are regulated by a Presidential Regulation in accordance with the mandate of Article 53 of Law No. 12 of 2011. Administrative matters regarding the design, submission, approval to become Laws, and the revocation of PERPU are regulated by a Presidential Regulation in accordance with the mandate of Article 53 of Law No. 12 of 2011. Administrative matters concerning the design, submission, approval to become Laws, and the revocation of PERPU are regulated by a Presidential Regulation in accordance with the mandate of Article 53 of Law No. 12 of 2011.

Regulated, regulated regarding the format of the PERPU formulation, and the determination and submission of it by the President of the DPR with the intention of being discussed to get a decision to be accepted or rejected by the DPR. In the event that the PERPU is approved by the DPR, it is also necessary to regulate how the PERPU format is converted into a law format. As a comparison, is it possible for the PERPU text to be equated with the text of the International Convention, and the RAPBN text which is translated into law with a text with attachments. Laws enacted by the DPR are only in the form of a written law, while the APBN and international conventions are placed as Annexes to Laws which are an integral part of the Law Text itself. Likewise, the law stipulated by the DPR is sufficient for one sheet only, while PERPU is used as an attachment that is inseparable from the Law. The law states the DPR's approval and sets the PERPU into effect as law. Meanwhile, if the PERPU is rejected, it is sufficient for the DPR to determine 1 sheet of DPR Decree which rejects it, so that on that basis, the President determines a Presidential Decree stating to revoke the rejecting PERPU.

\subsection{Analysis of Perpu No.1 of 2020}

To deal with and overcome the crisis due to the corona virus outbreak or covid-19, on March 31, 2020, President Joko Widodo has issued Government Regulation in Lieu of Law (PERPU) No. 1 of 2020 with a fairly long title, which is about "State Financial Policy and Financial System Stability for Handling the 2019 Corona Virus Pandemic (Covid-19) and / or in the context of Facing Threats that Endanger the National Economy and / or Financial System Stability". 5

In Article 28 Government Regulation in Lieu of Law (PERPU), There are 12 laws in which some of the provisions contained in YouTube do not apply as long as they are related to the policies specified in PERPU No. 1 of 2020. The 12 laws still exist and are in effect, but some of the provisions of the articles contained therein do not apply with regard to state financial policies for handling the spread of Corona Virus Disease 2019 (COVID-I9) and / or in the face of controlled threats national economy and / or financial system stability based on government regulations in lieu of this law. This means that with this PERPU, the provisions of

${ }^{5}$ LNRI of 2020 Number 87, TLNRI Number 6485. 
the articles mentioned in the 12 laws until or temporarily set aside, the goals achieved or in the Covid-9 report are declared to have ended.

The 12 laws which some of the provisions in it are enforced by PERPU No. 1 of 2020 are:

1) UU no. 6 of 1983 concerning General Provisions and Tax Procedures ${ }^{6}$ has been amended several times, most recently by Law Number 16 of 20009 concerning Stipulation of Government Regulations in Lieu of Law Number 5 of 2008 concerning the Fourth Amendment of Law Number 6 of 1983 concerning General Provisions and Tax Procedures into Laws; ${ }^{7}$

2) Act Number 23 of 1999 concerning Bank Indonesia ${ }^{8}$ has been amended several times, most recently by Act Number 6 of 20009 concerning Stipulation of Government Regulations in Lieu of Law Number 2 of 2008 concerning the Second Amendment of Act Number 23 of L999 concerning Bank Indonesia to become Act; 9

3) Law Number 17 of 2003 concerning State Finances; ${ }^{10}$

4) Law Number 1 of 2004 concerning State Treasury; ${ }^{11}$

${ }^{6}$ LNRI 1983 Number 49, TLNRI Number 3262, namely regarding the provisions for the time period regulated in Article 11 paragraph (21), Article 17B paragraph (1), Article 25 paragraph (3), Article 26 paragraph (1), and Article 36 paragraph (1c) Law Number 6 Year 1983 concerning General Tax Provisions and Procedures (State Gazette of the Republic of Indonesia Year 1983 Number 49, Supplement to the State Gazette of the Republic of Indonesia Number 32621 which has been amended several times, most recently by Law Number 16 Year 02009 concerning Stipulation Government Regulation in Lieu of Law Number 5 of 2008 concerning the Fourth Amendment to Law Number 6 of 1983 concerning General Provisions and Tax Procedures to Become Law (State Gazette of the Republic of Indonesia of 20009 Number 62, Supplement to the State Gazette of the Republic of Indonesia Number 4999) .

${ }^{7}$ LNRI Year 20009 Number 62, TLNRI Number 4999, namely Article 55 paragraph (41 Law Number 23 Year 1999 concerning Bank Indonesia (State Gazette of the Republic of Indonesia Year 1999 Number 66, Supplement to the State Gazette of the Republic of Indonesia Number 3843), has been amended several times, most recently by Act Number 6 of 20009 concerning the Stipulation of Government Regulations in lieu of Act Number 2 of 2008 concerning the Second Amendment to Act Number 23 of 1999 concerning Bank Indonesia to become Law (State Gazette of the Republic of Indonesia of 20009 Number 7, Supplement to the Republic of Indonesia Number 4962).

${ }^{8}$ LNRI 1999 Number 66, TLNRI Number 3843, namely Article 55 paragraph (41 Law Number 23 Year 1999 concerning Bank Indonesia (State Gazette of the Republic of Indonesia Year 1999 Number 66, Supplement to the State Gazette of the Republic of Indonesia Number 3843), which has been amended several times, most recently by Act Number 6 of 1992 concerning Stipulation of Government Regulations in Lieu of Law Number 2 of 2008 concerning Second Amendment to Act Number 23 of L999 concerning Bank Indonesia into Law (State Gazette of the Republic of Indonesia of 20009 Number 7, Supplement to the State Gazette of the Republic of Indonesia Indonesia Number 4962).

9 LNRI Year 20009 Number 7, LNRI Number 4962 Article 12 paragraph (3) namely along with the explanation, Article 15 paragraph (5), Article 22 paragraph (3), Article 23 paragraph (1), Article 27 paragraph (3), and Article 28 paragraph (3) in Law Number 17 Year 20003 concerning State Finances (State Gazette of the Republic of Indonesia Year 2003 Number 47, Supplement I, State Gazette of the Republic of Indonesia Number 4286).

${ }^{10}$ LNRI of 2003 Number 47, TLNRI Number 4286, namely Article 3 paragraph (3) of Law Number 1 of 2004 concerning State Treasury (State Gazette of the Republic of Indonesia of 2004 Number 5, Supplement to the State Gazette of the Republic of Indonesia Number 4355).

${ }^{11}$ LNRI Year $2 \mathrm{OO} 4$ Number 5, TLNRI Number 4355 namely Article 22 paragraph (2) and paragraph (3) Law Number 24 Year 2004 concerning the Deposit Insurance Corporation (State Gazette of the 
5) Law Number 24 of 2004 on the Deposit Insurance Corporation ${ }^{12}$ The agreement has been amended by Law Number 7 of 20009 concerning Stipulation of Government Regulations in Lieu of Law Number 3 of 2008 concerning Amendments to Law Number 24 of 02004 concerning the Deposit Insurance Corporation into Law; $;^{13}$

6) Law Number 33 of 2004 concerning Financial Balance between the Central Government and Regional Governments; ${ }^{14}$

7) Law Number 36 Year 20009 concerning Health; ${ }^{15}$

8) Law Number 6 Year $2 \mathrm{O} 14$ concerning Villages; ${ }^{16}$

9) Law Number 23 Year $2 \mathrm{OI} 4$ concerning Regional Government ${ }^{17}$ has been amended several times, most recently by Law Number 9 of 2015 concerning Second Amendment to Law Number 23 of $2 \mathrm{O} 14$ concerning Regional Government; ${ }^{18}$

Republic of Indonesia Year 20004 Number 96, Supplement to the State Gazette of the Republic of Indonesia Number 44201 has amended by Law Number 7 of 20009 concerning Stipulation of Government Regulations in Lieu of Law Number 3 of 2008 concerning Amendments to Law Number 24 of 02004 concerning the Deposit Insurance Corporation Into Law (State Gazette of the Republic of Indonesia of 20009 Number 8, Supplementary State Gazette of the Republic of Indonesia Number 4963).

${ }^{12}$ LNRI Year 2004 Number 96, TLNRI Number 4420 Article 27 paragraph (1) namely the explanation, Article 36, Article 83, and Article 10 paragraph (2) of Law Number 33 Year 2004 concerning Financial Balance between the Central Government and Regional Government (State Gazette Republic of Indonesia Year 20004 Number 126, Supplement to State Gazette of the Republic of Indonesia Number 4438).

${ }^{13}$ LNRI Year 20009 Number 8, TLNRI Number 49631, namely Article 171 of Law Number 36 Year 20009 concerning Health (State Gazette of the Republic of Indonesia Year 20009 Number 144, Supplement to State Gazette of the Republic of Indonesia Number 5063).

${ }^{14}$ LNRI Year 20004 Number 126, TLNRI Number 4438 Article 72 paragraph (2), namely along with the explanation of Law Number 6 Year $2 \mathrm{Ol} 4$ concerning Villages (State Gazette of the Republic of Indonesia Year 2000 Number 7, Supplement to the State Gazette of the Republic of Indonesia Number 5495).

${ }^{15}$ LNRI Year 20009 Number 144, TLNRI Number 5063 namely Article 316 and Article 317 Law Number 23 Year $2 \mathrm{OI} 4$ concerning Regional Government (State Gazette of the Republic of Indonesia Year $2 \mathrm{Ol} 4$ Number 244, Supplement to State Gazette of the Republic of Indonesia Number 5587) through Law Number several times. 9 of 2015 concerning the Second Amendment to Law Number 23 of $2 \mathrm{O} 14$ concerning Regional Government (State Gazette of the Republic of Indonesia of 2015 Number 58, Supplement to the State Gazette of the Republic of Indonesia Number 5679).

${ }^{16}$ LNRI Year 2014 Number 7 TLNRI Number 5495, namely Article 177 letter c number 2, Article 180 paragraph (6), and Article 182 of Law Number 17 Year 2014 concerning the Ralqrat Consultative Assembly, the House of Representatives, the Regional Representative Council and the House of Representatives Regions (State Gazette of the Republic of Indonesia Year $2 \mathrm{Ol}$ Number 182, Supplement to State Gazette of the Republic of Indonesia Number 5568) has been amended several times, most recently by Law Number 13 Year $2 \mathrm{OI} 9$ concerning the Third Amendment to Law Number 17 Year $2 \mathrm{O} 14$ concerning the People's Consultative Assembly, Council Ralryat Representatives, Regional Representative Council, and Regional Ralryat Representative Council (State Gazette of the Republic of Indonesia Year $2 \mathrm{Ol9}$ Number 181, Supplement to State Gazette of the Republic of Indonesia Number 6396).

${ }^{17}$ LNRI Year $2 \mathrm{Ol} 4$ Number 244, TLNRI Number 5587, namely Article 20 paragraph (2) and paragraph (3) Law Number 9 Year 2016 concerning Financial System Crisis Prevention and Management (State Gazette of the Republic of Indonesia Year 2016 Number 70, Supplement to the State Gazette of the Republic Indonesia Number 5872).

18 LNRI of 2015 Number 58, TLNRI Number 5679, namely Article 11 paragraph (221, Article 40, Article 42, and Article 46 of Law Number 20 Year $2 \mathrm{Ol} 9$ concerning the State Revenue and Expenditure 
10)Law Number 17 of $2 \mathrm{O} 14$ concerning the People's Consultative Assembly, the People's Representative Council, the Regional Representative Council, and the Regional People's Representative Council ${ }^{19}$ It has been amended several times, most recently by Law Number 13 of $2 \mathrm{OI} 9$ concerning the Third Amendment to Law Number 17 of $2 \mathrm{O} 14$ concerning the People's Consultative Assembly, the Ralryat Representative Council, the Regional Representative Council, and the Regional Ralryat Representative Council; ${ }^{20}$

11)Law Number 9 of 2016 concerning Prevention and Management of Financial System Crisis; ${ }^{21}$

12)Law Number 20 Year $2 \mathrm{Ol9}$ concerning the State Revenue and Expenditure Budget for Fiscal Year 2O2O.22

The 12 laws are declared invalid insofar as they are related to state financial policies for handling the 2019 Corona Virus Disease (COVID-I9) and / or in the context of facing threats that threaten the national economy and / or financial system stability based on Government Regulations in Lieu of Laws this. This means that with this PERPU, the provisions of the articles mentioned in the 12 laws until or temporarily set aside, the goals achieved or in the Covid-9 report are declared to have ended.

OnlyOf course, specifically regarding the Law on the 2020 FY State Budget, the impact of this countermeasures is different from the 11 other laws. First, the budget is only for 1 year, namely 2020. Second, the APBN reservation is the absolute right of the President to stay, and the absolute right of the DPR to declare or reject the consequences of the previous year's budget if the new draft is rejected. Therefore, the postponement statement for the APBN Law is identical to the budget change, which regulates the DPR's authority to agree or not. The President may not determine the amendment to the budget by himself, only because there is a situation of urgency which the President himself interprets. Therefore, it can be said, Article 28 PERPU No.

The provisions in all of the aforementioned laws are declared invalid insofar as they relate to state financial policies in the spread of the 2019 Corona Virus Disease (COVID-I9) and / or in the face of threats that threaten the national economy and / or financial system stability based on Government Regulation In Lieu of This Law. Thus, it is important to know that the ineffectiveness referred to only as long as this Perpu is valid and will be no longer there, either because it was rejected by the DPR-RI or for legal reasons that the enforcement of this PERPU has ended with recovery in the crisis caused by the Covid platform -19 , this PERPU by itself no longer exists, PERPU No. 1 of 2020 was issued as "financial policy and financial system stability for handling the 2019 corona virus pandemic (Covid-19) and / or in the context of dealing with threats that threaten the national economy and / or financial system stability". This means that the objectives of this PERPU are (i) to deal with the Covid-19 pandemic, and / or (ii) to face threats that endanger the national economy, and / or (iii) to maintain financial system stability.

These three things are also in the formulation of considerations (Considering Preferences) in this PERPU, namely:

Budget for Fiscal Year $2 \mathrm{O} 2 \mathrm{O}$ (State Gazette of the Republic of Indonesia Year $2 \mathrm{O} 19$ Number 198, Supplement to the State Gazette of the Republic of Indonesia Number 6410).

${ }^{19}$ LNRI Year 2014 Number 182, TLNRI Number 5568.

${ }^{20}$ LNRI Year 2 O19 Number 181, TLNRI Number 6396).

${ }^{21}$ LNRI of 2016 Number 70, TLNRI Number 5872.

${ }^{22}$ LNRI Year 2019 Number 198, TLNRI Number 6410. 
a. that the spread of Corona Virus Disease 2019 (COVID-19) which was declared by the World Health Organization as a pandemic in most countries around the world, including in Indonesia, has shown an increase over time and has caused casualties, and greater material losses, which have implications for social, economic and social welfare aspects;

b. The implications of the Corona Virus Disease 2019 (COVID-19) pandemic have an impact on, among other things, a slowdown in national economic growth, a decrease in state revenue, and an increase in state spending and financing, so that various Government efforts are needed to save health and the national economy, with a focus on spending for health, social safety nets, as well as economic recovery, including for businesses and communities affected;

c. Whereas the implications of the Corona Virus Disease 2019 (COVID-19) pandemic will also have an impact on the deterioration of the financial system as indicated by the decline in various domestic economic activities so that it needs to be jointly mitigated by the Government and the Financial System Stability Committee (KSSK) to take forward looking actions in the context of stability financial sector;

d. Whereas the policies in the policies referred to in letters a, b, and c, the Government and related institutions need to immediately take extraordinary policies and steps in the context of saving the national economy and financial system stability through various policies related to the implementation of the Income Budget. and State Expenditures (APBN) in particular with increased spending on health, spending on social safety nets, and economic recovery, as well as the authority of various institutions in the financial sector;

e. Whereas the conditions as referred to in letters $a, b$, and $d$, have met the parameter as internal urgency that gives authority to Government Regulations in Lieu of Laws regulated in Article 22 paragraph (1) of the 1945 Constitution of the Republic of Indonesia;

f. Whereas in the consideration for the Government as referred to in letter a, letter b, letter c, letter $\mathrm{d}$, and letter $\mathrm{e}$, as well as in order to provide a strong legal basis and related institutions to take such policies and steps very quickly, it is necessary to determine Government Regulation In Lieu of Law on State Financial Policy and Financial System Stability for Handling the 2019 Corona Virus Disease (COVID-19) Pandemic and / or in the Context of Facing Threats that Endanger the National Economy and / or Financial System Stability.

InThe general explanation of PERPU, also explained the background of implementing this PERPU, in which in $2 \mathrm{O} 2 \mathrm{O}$ the world experienced the Corona Virus Disease 2019 (COVID-19) pandemic. The spread of the Corona Virus Disease 2019 (COVID19) poses a risk to public health and has even claimed lives in various parts of the world, including Indonesia. The Corona Virus Disease 2019 (COVID-19) pandemic has significantly disrupted economic activity and had a major impact on the economies of most countries around the world [8], including Indonesia. Global economic growth has decreased from 3\% (three percent) to only $1.5 \%$ (one point five percent) or even lower. The development of the 2019 Corona Virus Disease (COVID-19) pandemic disrupts economic activity in Indonesia. One of the implications is the decline in Indonesia's economic growth which is estimated to reach $4 \%$ (four percent) or lower. This affects how long and no matter the spread of the Corona Disease 
2019 (COVID-19) pandemic affects and even cripples community activities and economic activities.

The disruptionEconomic activities that affect changes in the State Revenue and Expenditure Budget Posture (APBN) for Fiscal Year 2O2O. Whether it's changes in State Revenue, State Expenditures, or Financing. Potential changes to the $2 \mathrm{O} 2 \mathrm{O}$ Fiscal Year State Budget occur due to disruption to economic activity or somewhat. Disruption to economic activities that disrupts the State Budget for the 2O2O Fiscal Year from the State Revenue. The response to state financial and fiscal policies needed to deal with the risk of the 2019 Corona Virus Disease (COVID-19) pandemic includes increasing spending in the context of mitigating health risks, protecting the public and maintaining business activities. Pressure on the financial sector will affect the $2 \mathrm{O} 2 \mathrm{O}$ State Budget for Fiscal Year, especially on Financing.

In accordance with the Decision of the Constitutional Court Number 138 / PUU-VII 20009 , the aforementioned conditions have met the parameters as urgent that are included in the framework of enacting Government Regulations in Lieu of Law, among others:

a. because of the need for requirements to quickly resolve legal problems based on the Act;

b. The required law does not exist yet, resulting in legal vacuum or inadequacy of existing laws; and

c. a condition of legal vacuum that cannot be resolved by making laws in a procedural manner which requires a long time while the proximity of the situation requires certainty to develop.

Based on the foregoing matters, in an incoming crisis, in accordance with the provisions of Article 22 paragraph (1) of the 1945 Constitution of the Republic of Indonesia, the President shall stipulate a Government Regulation in Lieu of a Law. However, it is necessary to remember that all the critical considerations mentioned are not seen in the perspective of the dangers referred to by Article 12 of the 1945 Constitution. Therefore, in considering this PERPU, Article 12 of the 1945 Constitution is not mentioned and touched at all. PERPU No. 1 of 2020 is stipulated only by keeping in mind the provisions of Article 22 paragraph (1) of the 1945 Constitution of the Republic of Indonesia. This means that this PERPU is still under the legal regime in ordinary circumstances. It is not an emergency legal regime or a state of emergency by Article 12 of the 1945 Constitution of the Republic of Indonesia. In addition, apart from this PERPU, Law no. 24 of 2007 concerning Disaster Management and Law no. 6 of 2018 concerning Health Quarantine also does not apply at all with or in the context of implementing Article 12 of the 1945 Constitution. In the preamble, considering that in the last two laws, Article 12 of the 1945 Constitution is also not mentioned as a reference. This means that although the material stipulated regarding disaster diversion and on health emergencies, it is still stipulated not in the context of state conditions in a state of disaster emergency as stipulated in Article 12 of the 1945 Constitution. 24 of 2007 concerning Disaster Management and Law no. 6/2018 concerning Health Quarantine also does not support or in the context of implementing Article 12 of the 1945 Constitution. In the preamble, considering that in the last two laws, Article 12 of the 1945 Constitution is also not mentioned as a reference. This means that even though the material stipulated regarding disaster diversion and health emergencies, it is still determined not in the context of state conditions in a state of disaster emergency as stipulated in Article 12 of the 1945 Constitution. 24 of 2007 concerning Disaster Management and Law no. 6/2018 concerning Health Quarantine also does not support or in the context of 
implementing Article 12 of the 1945 Constitution. In the preamble, considering that in the last two laws, Article 12 of the 1945 Constitution is also not mentioned as a reference. That is,

Therefore, it can be said that, both Law no. 24 of 2007, Law no. 6 of 2018, as well as PERPU No. 1/2020 are both laws that were formed when the state was in a normal state, not when the state was in an emergency state by Article 12 of the 1945 Constitution as the only article of the 1945 Constitution that addresses this emergency situation. All three are laws that are in a normal state, so that the whole system is also in a normal state. In a normal legal regime, all laws and regulations that remain binding to the public, except those that have been expressly regulated in the second provisions of the Law on Disaster Management, and the Law on Health Quarantine, are now added with PERPU. No.1 of 2020,

The differences between normal and emergency legal regimes are markedly different from one another. In ordinary circumstances or norms, normal laws apply. If the law of normalcy was applied to an emergency, there would be no justice. Likewise, if under normal circumstances a law that should have been intended for emergencies or is not normal is enforced, then no justice will be generated. The principle that must be adopted is "normale rechts voor normale tijd, en attr abnormal rechts voor abnormal tijd". (Normal law for abnormal time, and abnormal law for abnormal time).

Abnormal circumstances can protect citizens, or even the safety of the nation and state. Of course, not all experts regarding the existence of the two legal regimes use this "dualism" approach. However, according to John Ferejohn and Pasquale Pasquino [9],

"In this case, the constitution which has provisions on emergency personnel already shows a dualistic element: there are two different normative systems, which are mutually isolated: a normal system of rights and procedures and a normative system that operates in an emergency. This also applies to the legislative emergency model. "(In this connection, a constitution that contains provisions regarding the power of an emergency state of a dualistic element, the existence of two different norm systems, which are separate from one another. A normative system that regulates normal rights and procedures and a normative system that functions in a state of affairs This is true, in the executive function as well as in the model of the legislative function).

However, because PERPU No. 1 of 2020 does not mention Article 12 of the 1945 Constitution at all in its 'consideration', so it can be ascertained that this PERPU is substantially the same as its legal status as Law No. 24 of 2007 concerning Disaster Management, and with Law no. 6 of 2018 concerning Health Quarantine. All three are laws that are enforced under normal circumstances. Thus, the implementation of these three laws must not violate other laws, violate human rights, let alone violate the 1945 Constitution. If all three violate the 1945 Constitution, then as long as someone submits a petition for review of their constitutionality, the Constitutional Court can at any time cancel or declare these three laws are invalid because they are proven to have violated the 1945 Constitution.

The stipulation of PERPU No. 1 of 2020 the enactment of various provisions in 11 laws and amending the material of 1 law, namely the APBN Law described above. However, apart from matters that are official or amended by this PERPU, the other provisions of the Law are still and must not be violated. Such is the law that PERPU has not changed or enacted, means that it is still what it is, so that it cannot be violated in the implementation of PERPU No. 1 of 2020. Of course there are many examples that can be referred to as examples. For example, the prohibition of carrying out Friday prayers in mosques, or later for tarawikh prayers in the holy month of Ramadan. With all the dignity of intent and content for the nation and humanity, the Police can act to protect the people and gather in mosques which under ordinary 
circumstances is a real human right. Is it with PERPU No. 1 of 2020 , can such violations of human rights be justified? The answer is not clear, because PERPU No. 1 of 2020 is only to overcome conditions in the economic and financial sector. The contents of the PERPU are only financial policies and financial system stability for handling the Covid-19 pandemic and / or in the context of facing threats that threaten the national economy and / or financial system stability. because the purpose of PERPU No. 1 of 2020 is only to overcome conditions in the economic and financial sector. The contents of the PERPU are only financial policies and financial system stability for handling the Covid-19 pandemic and / or in the context of facing threats that threaten the national economy and / or financial system stability. because the purpose of PERPU No. 1 of 2020 is only to overcome conditions in the economic and financial sector. The contents of the PERPU are only financial policies and financial system stability for handling the Covid-19 pandemic and / or in the context of facing threats that threaten the national economy and / or financial system stability.

Likewise with Law no. 6 of 2018 concerning Health Quarantine. In the preamble, this Law also does not mention Article 12 of the 1945 Constitution concerning the state of danger, but only Article 5 paragraph (1), Article 20, Article $28 \mathrm{H}$ paragraph (1), Article 34 paragraph (3) of the Constitution of the Republic of Indonesia 1945. Part Five of this Law regulates Large-Scale Social Restrictions (PSBB), namely in Article 59 which stipulates:

(1) Large-Scale Social Restrictions are part of the Public Health Emergency response;

(2) Large-Scale Social Restrictions are aimed at preventing the spread of an ongoing Public Health Emergency between people in a certain area;

(3) Large-scale social restrictions, the people referred to in paragraph (1) include at least:

a. school and work vacations;

b. religious event; and / or

c. activities in public places or facilities.

(4) The Organization of Large-Scale Social Restrictions in coordination and cooperation with various parties related to the provisions of laws and regulations.

Article 59 paragraph (3), especially in the letter 'b', for example, by closing the mosque on Friday, can be said to be a real violator of human rights which can only be done by the state officially declared as in a state of civil emergency. What happens if the provisions of Article 59 paragraph (3) with clear evidence from the facts on the ground that mosques are forced to close for weeks or even months, for whatever reason, can still violate the principle of religious freedom guaranteed in the Constitution 1945. If the law is tested before the Constitutional Court, then the panel of judges must tolerate it not on the basis of consideration of the enactment of Article 12 of the 1945 Constitution? If other articles are used, the provisions of Article 59 of Law no. 6 of 2018 is contrary to the 1945 Constitution.

Especially regarding PERPU No. 1 of 2020, it can be said, the status is somewhat different regarding Law no. 6 of 2018 and Law no. 24 of 2007 which has officially become a law. PERPU, according to Article 22 paragraph (2) of the 1945 Constitution, to become law still has to obtain approval from the DPR. If it does not get approval, according to Article 22 paragraph (3) of the 1945 Constitution, the PERPU must be revoked. The problem is, if the PERPU later gets approval from the DPR, the material provisions in it will apply forever, even though, its contents are limited to and in the context of dealing with the threat of the Covid-19 
outbreak. If the state of the Covid-19 epidemic crisis has ended and the situation returns to normal, then of course, the existence of PERPU No.

From the meaning and understanding and understanding in terms of the policy material outlined, led to PERPU No. 1 of 2020 is very different from other PERPUs that have been established. The existing PERPU criterion is PERPU which is really stipulated as a law which is within the stipulated time and it is impossible for refugees to be approved and approved together in a hearing at the DPR. This means that the substance of the PERPU is essentially a law, but due to time constraints it cannot be regulated according to the usual statutory order procedures, so it must be stipulated by PERPU. However, PERPU No. 1 of 2020, the contents of the policy material set forth in it are truly temporary during a crisis situation due to the Covid-19 epidemic. In fact, PERPU No. 1 of 2020 is also set to overcome a crisis situation related to the threat of the Covid-19 outbreak. Specifically, the aims and answers in the title of this PERPU, namely: regarding "state financial policies and financial stability for handling the 2019 coronavirus pandemic (Covid-19) and / or in order to face threats that threaten the national economy and / or stop the financial system ".

Therefore, after later in the next trial period, the President will convey PERPU No. 1/2020 DPR for the purpose of obtaining approval, there must be different considerations from the DPR or the President regarding this PERPU when compared to other PERPUs which are term in nature. length of statute in general. First, the President must deliberately explain that this PERPU is temporary to overcome the Covid-19 pandemic outbreak, which is likely to end the threat of the Covid-19 outbreak, so the reason for the existence of PERPU No. 1 Year 2020 will automatically disappear. Second, the DPR itself must also accept the submission of PERPU No. 1 of 2020 with a flexible attitude in accordance with the aims and objectives of the stipulation of PERPU No. 1 of 2020. Both the Government and the DPR must assess the development of the situation to what extent the threat of the Covid-19 outbreak can be said to have ended or not. If it is still not over, the health emergency can be extended in accordance with the authorities determined based on the provisions of Article 8 letter d PERPU No. 1 of 2020 which states, "the determination of the time period for force majeure due to the 2019 Corona Virus Disease pandemic (COVID-19) is regulated as referred to in letters a, b, and c refers to the determination of the Government through the Head of the National Disaster Management Agency".

Because the rights are indeed temporary, the Government may not file the PERPU at all to get the DPR's approval. This is because the provisions of Article 22 paragraph (2) of the 1945 Constitution which states "this Government Regulation must be approved by the DPR in the following proceedings". This means that PERPU must be submitted to the DPR with the intention of obtaining approval to become the law it should be. However, if the situation returns to normal and the PERPU is no longer needed, then there is no need to get DPR approval either. In the absence of DPR approval, PERPU must be revoked by itself. To revoke it, of course it is sufficient to do it unilaterally by the President himself,

In my opinion, the provisions regarding the revocation of PERPU which are required by this bill, in my opinion, are a fatal mistake. But because it has been regulated in the Law on Prevailing Laws, we can understand it in two categories, namely (i) PERPU with long-term objectives as ordinary laws, and (ii) PERPU with short-term goals to overcome the situation. in an emergency, such as PERPU No. 1 of 2020. For the time being, the first category PERPU can be revoked by the procedure stipulated by the Law concerning Prevailing Laws, however, for the second category PERPU, such as PERPU No. 1 of 2020, it is not enough that it is not enough for the DPR, so that by not getting the approval of the DPR, the PERPU is no longer right in time, 
Even if PERPU No. 1 of 2020 is submitted to the DPR, the DPR must understand that the purpose of this PERPU is only temporarily approved to become a permanent law. Even though the purpose and contents are only temporary. Because of that, the DPR did not actually enforce this PERPU so that in time it had to be revoked. It's just that, the problem is, because the state of emergency as a threat to the Covid-19 outbreak cannot be determined how long it will take, so the next session of the DPR as referred to in Article 22 paragraph (2) of the 1945 Constitution is uncertain.

If we follow the provisions of Article 22 paragraph (2), the PERPU will take effect without the approval of the DPR, which will take no longer than the next session, which is 3-5 months after the issuance of PERPU No. 1 Year 2020, on March 31, 2020. ${ }^{23}$ If the national disaster of the Covid-19 outbreak lasts more than 5 months ahead, then there is no other way for the President, except to comply with the provisions of Article 22 paragraph (2) of the 1945 Constitution, namely having to submit the PERPU to the DPR for approval or disapproval in the trial the following. If the discussion in the DPR regarding PERPU No.1 / 2020 occurs, then there are several scenarios that need to be tried, namely:

1) PERPU No. 1 of 2020 is declared rejected, so according to Article 22 paragraph (3) of the 1945 Constitution, the PERPU must be revoked;

2) PERPU No. 1 Year is declared 2020 for a while until the Covid-19 disaster ends, which time is submitted to be determined by the President cq the Head of BNPB as Chair of the Covid-19 Handling Task Force;

3) PERPU No. 1 of 2020 is declared rejected and must be revoked by the President;

4) PERPU No. 1 of 2020 is declared rejected and must be repealed by the Bill on the Revocation of PERPU.

Another option is that the discussion and decision making in the DPR regarding PERPU No. 1 Year 2020 should be postponed until the Covid-19 business or at least until the estimate of the end of the Covid-19 crisis can be known with certainty. We must focus on resolving the danger of Covid-19 which threatens the safety of all citizens. "Salus populi, suprema lex esto", salvation is the highest law, and the people must take precedence over everything. PERPU No. 1 of 2020 is actually needed to deal with and overcome the Covid-19 emergency for a while, so it should not be declared rejected, because it is needed for the safety of the people. However, the DPR should not declare the PERPU, because by acceptance it means that PERPU will become a permanent law.

As stated above, PERPU No. 1/2020 cannot be categorized as a PERPU for and in an emergency situation because it does not comply with the provisions of Article 12 of the 1945 Constitution. The provisions of Article 12 state, "The President declares a state of danger. The conditions and consequences of a state of danger are stipulated by law". From Article 12 it can be seen that:

1) The conditions and legal consequences of such a state of danger shall be determined by law. With a statement that the statement of the state of danger is stipulated by law in

\footnotetext{
${ }^{23}$ According to the provisions of Article 22 paragraph (2) of the 1945 Constitution, people are repeated by Article 52 paragraph (1) of Law no. 12 of 2011, PERPU must obtain the approval of the DPR-RI at the latest in the following trials. In the Elucidation of Article 52 Paragraph (1), it is emphasized that "What is meant by" the following trial "is the period of the first session after the Government Regulation in Lieu of a Law is enacted."
} 
accordance with the specific policy policies that are put in place to solve the problem and return to its original state; and

2) The terms and legal consequences of the circumstances are further stipulated in and the law includes. Until now, the law that is still in effect on this is Law no. 23 of 1959 concerning the State of Danger. However, many of the contents of this Law are no longer in accordance with the times. Including the new provisions of the 1945 Constitution after the First, Second, Third and Fourth Amendments in 1999-2002.

PERPU No. 1 of 2020 is in no way related to and not the implementation of Article 12 of the 1945 Constitution quoted above. Therefore, this PERPU in terms of its form is an ordinary law that cannot conflict with the 1945 Constitution, and may not suspend or override the enactment of other statutory provisions and let alone the provisions of the 1945 Constitution. However, in terms of content, PERPU No. 1 Year 2020 is only sustainable for a while as long as the crisis situation due to Covid-19 has not ended. PERPU is not appropriate to represent the provisions of the various laws in force. Because of that, PERPU No. 1 of 2020 also cannot conflict with the 1945 Constitution or other laws that do exist to be based on the 1945 Constitution. In short, PERPU No. 1 In 2020, it is necessary to practice only until the Covid19 crisis is resolved. After that, it must be ensured that this PERPU will actually be revoked on time.

In addition, PERPU No. 1 of 2020, it is also not appropriate for treatment as a special PERPU to enforce emergencies and be specifically applied for and in the context of emergencies due to Covid-19. Because in terms of substance, this PERPU only regulates "State Financial Policy and Financial System Stability for Handling the Corona Virus Desease 2019 (Covid-19) Pandemic", and / or (ii) in the context of Facing Threats that Endanger the National Economy and / or Stability. Financial System "only. This PERPU does not regulate all government actions that must be taken during the Covid-19 emergency. The substance really comes from the interests of economic and financial policy makers only. The ministry of ministries in the coordination ranks of the Coordinating Ministry for Political, Legal and Security Affairs and the Coordinating Ministry for Human Development and Culture have no idea whatsoever to formulate new policies during the Covid-19 crisis. So the threat of Covid19 is the task of all state ministries.

PERPU No. 1 of 2020 is very inadequate as a legal instrument that guides and guides the implementation of government tasks in facing the threat of the Covid-19 outbreak. The content is too narrow with regard only to financial policies, the economy only. Therefore, its enforcement cannot be used as a basis for government actions in other fields which must still comply with and carry out all regulations that are in a proper state during normal circumstances. In fact, the situation that arises due to the threat of Covid-19 is out of the ordinary and must admit to having crashed, bypassed, and breached many provisions of the statutory regulations, which if they do not enter into force,

First, PERPU No. 1 of 2020 there is no law in general, starting with formulating general provisions containing definitions of meaning. PERPU No. 1/2020 by no means limits the meaning of very abstract concepts, such as financial policies, financial system stability, threats that threaten the national economy and / or financial system stability, etc. Therefore, in its implementation, the interpretation of the aforementioned terms will greatly depend on the implementing officials to narrow down or expand the meaning.

Second, PERPU No. 1 of 2020 directly and contains new policies in 29 articles which are divided into 5 chapters, namely (I) Scope, (II) State Financial Policy, (iii) Financial System 
Stability Policy, (IV) Sanctions, and (VI) ) Closing. In Chapter I, Article 1, it is clearly stipulated that the scope of this regulation by PERPU only serves:

(1) In order to meet the needs of state governance, a State Revenue and Expenditure Budget (APBN) is prepared, which consists of the state revenue budget, state expenditure budget, and budget financing;

(2) To implement the State Revenue and Expenditure Budget (APBN) as referred to in paragraph (1), Law Number 20 Year $2 \mathrm{OI} 9$ concerning the State Revenue and Expenditure Budget for Fiscal Year $2 \mathrm{O} 2 \mathrm{O}$ has been enacted;

(3) To implement the State Revenue and Expenditure Budget (APBN) as referred to in paragraph (1) and paragraph (2) in the framework of:

a. handling of the Corona Vruts Disease 2019 (COVID-19) pandemic and / or

b. Threats that threaten the national economy and / or financial system stability need a second state policy and a system stability policyngan.

(4) (2) State financial policies as referred to in paragraph (3) include state revenue policies including policies in the field of taxation, policies on state spending policies in the field of regional finance, and policies for financing;

(5) (3) The financial system financial policy as referred to in paragraph (3) includes policies for crisis management, financial institutions experiencing financial crises and financial system stability.

Third, in Chapter II on State Finance Policy, policies that change various provisions in the Law on State Finance and other related Laws are regulated, which are properly implemented and will conflict with many other laws and also with the 1945 Constitution. PERPU only watches with the State Finance Law, the Taxation Law, the State Treasury Law, the Bank Indonesia Law, the Deposit Insurance Corporation Law, the Law on Fiscal Balance between the Central and Local Government, and the Law on Financial System Crisis Prevention and Handling, as well as the Law on Revenue and the Dutch Budget. State Year 2020. Because it is related to the Covid-19 crisis throughout the country, this PERPU also cares for the material of the Law on Health, as well as with the Law on Regional Government only. For example, This PERPU does not participate in the enforcement of several articles in the Law on Human Rights, the Law on the National Education System, the Law on Trade, the Law on Cooperatives, and so on, which in practice all have been affected by the growing threat of the Covid-19 virus pandemic. PERPU No. 1 of 2020 only focuses on financial sector policies. It is very clear that only officials from the financial sector took the initiative to issue PERPU. 1 of 2020 only focuses on financial sector policies. It is very clear that only officials from the financial sector took the initiative to issue PERPU. 1 of 2020 only focuses on financial sector policies.

Inin one sense, this is a compliment to officials in the financial sector who have their hearts and minds to initiate special policies in the context of handling the Covid-19 outbreak. This is at the same time an embarrassing mockery for officials in other sectors, how come they are not at all moved to formulate specific policies in their respective fields. Even though it is clear that the impact of the Covid-19 pandemic is the safety of the Indonesian people, except and certainly will have an impact on all sectors of government and national development. Where do law graduates sit in government, how can they enjoy their positions without feeling of responsibility to contribute to handling the threat of Covid-19. But on the other hand, What is even more important is that the policies contained in this PERPU are very limited only with regard to financial sector policies. Of course, in practice services and action steps taken in the field are very limited, because they cannot be a guide and reference in all interrelated sectors. 
If officials in the financial sector receive immunity according to the provisions of Article 27, does it mean that officials in other fields, who have also made breakthroughs by bypassing the law, will be left to be accountable for themselves due to their work in the realm of criminal law, without protection. In fact, they also had to make breakthroughs that violated the problems related to Covid-19. because it cannot become a guide and reference in all interrelated sectors. If officials in the financial sector receive immunity according to the provisions of Article 27, does it mean that officials in other fields, who have also made breakthroughs by bypassing the law, will be left to account for themselves for their work in the realm of criminal law, without protection. In fact, they also had to make breakthroughs that violated the problems related to Covid-19. because it cannot become a guide and reference in all interrelated sectors. If officials in the financial sector receive immunity according to the provisions of Article 27, does it mean that officials in other fields, who have also made breakthroughs by bypassing the law, someday he will be left to account for himself due to his work in the realm of criminal law, without protection. In fact, they have also made breakthroughs that violate the problems related to Covid-19. someday he will be left to account for himself due to his work in the realm of criminal law, without protection. In fact, they also had to make breakthroughs that violated the problems related to Covid-19. someday he will be left to account for himself due to his work in the realm of criminal law, without protection. In fact, they also had to make breakthroughs that violated the problems related to Covid-19. they also have to make breakthroughs that violate the problems related to Covid-19. someday he will be left to account for himself due to his work in the realm of criminal law, without protection. In fact, they also had to make breakthroughs that violated the problems related to Covid-19. someday he will be left to account for himself due to his work in the realm of criminal law, without protection. In fact, they also had to make breakthroughs that violated the problems related to Covid-19. they also have to make breakthroughs that violate the problems related to Covid-19. someday he will be left to account for himself due to his work in the realm of criminal law, without protection. In fact, they also have to make breakthroughs that violate the problems related to Covid-19. someday he will be left to account for himself due to his work in the realm of criminal law, without protection. In fact, they have also made breakthroughs that violate the problems related to Covid-19. they also have to make breakthroughs that violate the problems related to Covid-19. someday he will be left to account for himself due to his work in the realm of criminal law, without protection. In fact, they have also made breakthroughs that violate the problems related to Covid-19. they also have to make breakthroughs that violate the problems related to Covid-19. someday he will be left to account for himself due to his work in the realm of criminal law, without protection. In fact, they also had to make breakthroughs that violated the problems related to Covid-19.

Therefore, it can be said that this PERPU has not yet resolved the problem of the need for special policies that have been implemented to deal with the Covid-19 problem. In fact, if the new policies in this PERPU later turn out to be applied permanently, for example by obtaining the approval of the DPR according to the applicable provisions, it can be hoped that this PERPU will cause more complications related to the legal system and the Indonesian economic constitution. . This is because this PERPU has put aside so many provisions of the Law which have been standardized but are permanently amended by PERPU, all of which are only temporary. For this reason, the Government and the DPR must respond to this PERPU appropriately, not to be struggled or idealized to obtain the approval of the DPR as PERPU in general. PERPU No. 1 of 2020 is a different PERPU, which is only temporary, so that in time after its function to deal with the Covid-19 crisis is declared complete, the DPR must refuse to 
reject this PERPU, and on that basis PERPU is revoked and does not become a permanent law.

\section{Conclusion}

Thus, in order to face the threat of the dangers of Covid-19, the Government should have issued (i) a Presidential Decree which states the enactment of the Covid-19 Danger State; (ii) PERPU concerning State of Danger as the elaboration of Article 12 of the 1945 Constitution which is intended to amend or replace Law no. 23 of 1959; (iii) PERPU concerning Covid-19 Hazard Management in 2020 which contains special policies that diverge temporarily from various provisions of the Law which wish to overcome emergencies until normal conditions are restored;

PERPU No. 1 of 2020 is very inadequate as a legal instrument that guides and guides the implementation of government tasks in facing the threat of the Covid-19 outbreak. The content is too narrow with regard only to financial policies, the economy only. Therefore, its enforcement cannot be used as a basis for government actions in other fields which must still comply with and carry out all regulations that are in a proper state during normal circumstances. In fact, the situation that arises due to the threat of Covid-19 is out of the ordinary and must admit to having crashed, bypassed, and breached many provisions of the statutory regulations, which if they do not enter into force,

\subsection{Recommendation}

Based on the description above, it can be seen that PERPU No. 1 of 20202 has many problems that can cause various legal complications in its implementation and application. Among those that have been stated above as remedial solutions, there are several alternative solutions that can be achieved to overcome this PERPU Covid-19 legal problem.

First, from the President's side, the following things can be done:

1) PERPU No. 1 of 2020 can improve the conditions in Article 12 of the 1945 Constitution in the consideration given that it was preceded by an official stipulation by the President declaring that the country was in a state of emergency Covid-19. However, the disadvantage is that it can be faulted too late, and creates uncertainty;

2) The President deliberately did not send or submit the PERPU to the DPR to ask for approval, so that the discussion in the DPR to accept or reject can state until there is certainty when Covid-19 will end. However, the weakness is that this could violate Article 22 paragraph (2) of the 1945 Constitution which states, "This government regulation must be approved by the DPR in the following trial". Therefore, PERPU must be submitted to the DPR at the latest before the following session period.

Second, from the DPR side after receiving the PERPU submission from the President, several alternative actions can be taken as follows:

1) The decision to postpone the decision to determine or reject PERPU until the right time when the threat of Covid-19 can be predicted with certainty when it will end. But the weakness is because according to Article 22 paragraph (2) of the 1945 Constitution, which is repeated by Article 52 paragraph (1) of Law no. 12 of 2011, PERPU must obtain the approval of the DPR-RI at the latest in the following trials. If it is not approved, it 
means that PERLU is rejected and according to Article 22 paragraph (3) of the 1945 Constitution, PERPU must be revoked.

2) Declaring the prohibition or not applying the PERPU into law, and in accordance with the provisions of Law no. 12 of 2011, the revocation is carried out by means of a law which also regulates the time for the end of the Covid-19 crisis and the legal consequences of the revocation of the PERPU. The weakness is political, that is, can the Government together with the coalition political parties state firmly in public reject PERPU No. 1 of 2020, so that PERPU must be revoked.

Third, from the perspective of the Constitutional Court, which must face the examination of applications from various circles of society who think that PERPU No. 1/2020 contradicts the 1945 Constitution. The alternatives are:

1) The Court rejected the examiner's request by confirming the constitutionality of PERPU No. 1 of 2020 with notes (i) on your own to deal with the emergency threat of the Covid19 pandemic outbreak (Conditionally Constitutional); and (ii) After the end of the threat of epidemic, PERPU must be revoked.

2) The Court granted the petition by stating PERPU No. 1 of 2020 contradicts the 1945 Constitution with conditions (Conditionally Unconstitutional), for example, (i) it is still ongoing until the end of the Covid-19 pandemic, (ii) all legal consequences that have arisen during the enactment of PERPU No. 1 of 2020 remains valid and precise until the PERPU is declared no longer based on the Constitutional Court decision.

Fourth, what is important is that in principle there is a need for the same perception among all policy makers regarding the Covid-19 problem and how to overcome it. On the one hand, PERPU No. 1 of 2020 is very much needed to overcome various problems during the Covid-19 crisis and return the situation to normal, but other parties have weaknesses that must be overcome so that they do not cause troublesome legal consequences in the future.

And lastly, it is hoped that the threat of the dangers of Covid-19 can unite all of the nation's children, namely the common interest for common safety and even for the safety of the state and nation from the threat of the dangers of Covid-19. Stop using Covid-19 for your own political gain and politics that will be enjoyed by other parties who are not liked. Stop looking at Covid-19 from a political perspective, branding for yourself or other parties. Stop cursing, blaming, memorizing and being hostile to other parties and / or territories over yourself, worshiping one's own idol, glorifying one's own group, all of which are narrow and mediocre political motives. The Covid-19 threat is a threat to safety for all of us and even for all of humanity. Let us unite to face and overcome it, regardless of political attitudes and political polarization in society. "Salus poluli suprema les esto", people's safety is the highest law. "Legem non alphabetical necessity". The importance of salvation has no law, but the interest itself is the law.

\section{References}

[1] World Health Organization, International Health Regulations 2005, Geneva: WHO, 2008.

[2] Republic of Indonesia, Presidential Decree No. 11 of 2020 concerning the Determination of Public Health Emergencies for Corona 19 Virus Disease (COVID19), Jakarta: Cabinet Secretariat of the Republic of Indonesia, 2020. 
[3] Republic of Indonesia, Presidential Decree No.12 of 2020 concerning the Determination of Non-Natural Disaster for the Spread of Corona Virus Disease 19 (COVID-19) as a National Disaster, Jakarta: Cabinet Secretariat of the Republic of Indonesia, 2020.

[4] J. Asshiddiqie, Emergency Constitutional Law, Jakarta: Rajagrafindo Persada, 2007.

[5] J. Asshiddique, Consolidation of the 1945 Constitution after the fourth amendment, Jakarta, 2003.

[6] S. Soekanto, Introduction to Legal Research, Jakarta: UI Press, 1986, p. 6.

[7] CF Strong, History of Modern Political Constitutions, FRANKLIN CLASSICS TRADE Press, 2018.

[8] MK Mishra, „The world after COVID-19 and its impact on the Global Economy,“ ZBW - Leibniz Information Center for Economics, Kiel, Hamburg, 2020.

[9] J. Ferejohn a P. Pasquino, The Law of Exceptions: Typology of Emergency Force, zv. 2, New York: Oxford University Press and New York University School of Law, Con. 2004, p. 210-239. 